\title{
Assessment of levels of Vitamin D and Leptin in comparison of BMI among medical students
}

\author{
Sivakumar J. ${ }^{1 *}$, Sampson U. ${ }^{2}$, Kumar J. ${ }^{3}$ \\ DOI: https://doi.org/10.17511/ijmrr.2020.i01.08
}

1* Sivakumar J., Assistant Professor, Department of Biochemistry, Meenakshi Medical College, Kancheepuram, Tamil Nadu, India.

2 Ursula Sampson, Professor and Head, Department of Biochemistry, Meenakshi Medical College, Kancheepuram, Tamil Nadu, India.

3 Kumar J., Tutor, Department of Biochemistry, Meenakshi Medical College, Kancheepuram, Tamil Nadu, India.

Introduction: Vitamin $D$ is one of fat-soluble vitamin that plays an important role in the absorption of calcium and phosphate. Deficiency of Vitamin D is unrecognized in many parts of the world. Leptin is a hormone which is derived from adipose tissue. Studies have shown that vitamin D has a negative and powerful control on leptin secretion by vitamin D by acting on the adipose tissue. Aim and Objectives: The study was done to study the relationship between Vitamin D and Leptin based on Body mass index among the medical students. Materials and methods: Vitamin D Leptin and Body mass index were the parameters measured in the study group. Individuals with an age group of 19-23 years of both sexes were included in the study. Individuals above the age of 23 years, those with renal and liver disorders, individuals with hormonal disorders, individuals on vitamin $D$ supplementation were excluded in the study. Vitamin D was measured by Enzyme-Linked Immunosorbent Assay (ELISA) method. Leptin was measured by Enzyme-Linked Immunosorbent Assay (ELISA) method. BMI is calculated by the formula weight in kilograms divided by height in metre square. Results: The results have shown that there is a decrease in vitamin $D$ levels with increasing BMI. (pvalue $\leq 0.001$ ). furthermore, there is an increase in leptin levels with an increase in BMI. (pvalue 50.001 ). Conclusion: The study has put forth a suggestion that leptin and vitamin D has a causal relationship between them based on Body Mass index. Adequate vitamin D levels will maximize the effect of maintaining normal leptin levels as high levels of leptin could contribute to obesity-related disorders.

Keywords: Vitamin D, Obesity, Leptin

\section{Corresponding Author}

Sivakumar J., Assistant Professor, Department of Biochemistry, Meenakshi Medical College, Kancheepuram, Tamil Nadu, India. Email: drshivakumar21@gmail.com

\section{How to Cite this Article}

Sivakumar J, Sampson U, Kumar J. Assessment of levels of Vitamin D and Leptin in comparison of BMI among medical students. Int J Med Res Rev. 2020;8(1):51-56.

Available From

https://ijmrr.medresearch.in/index.php/ijmrr/article/ view/1133
To Browse

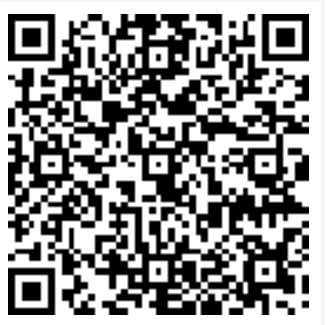

Manuscript Received 2020-01-05

Conflict of Interest No

(c) 2020 by Sivakumar J., Ursula Sampson, Kumar J. and Published by Siddharth Health Research and Social Welfare Society This is an Open Access article licensed under a Creative Commons Attribution 4.0 International License https://creativecommons.org/licenses/by/4.0/ unported [CC BY 4.0].
Review Round 2 2020-01-20 2020-01-15

unding
Review Round 3

Accepted 2020-01-24

Note 


\section{Introduction}

Vitamin $D$ is one among the fat-soluble vitamins. Absorption of Calcium and Phosphate is one of the important functions of vitamin D. vitamin D2 and vitamin D3 are important related compounds [1]. Deficiency of vitamin $D$ is seen in many parts of the world [2]. It is reported among various sections of the people which includes both males and females ranging from young age group to older people [1]. Recent studies have shown that there is an increased prevalence of hypovitaminosis of vitamin D among Spanish medical students. Another study has reported that there is decreased vitamin $D$ levels among $87.5 \%$ of Indian resident doctors [3]. From the above studies it is clear that there are low vitamin $D$ levels among young medical students which raises a concern about the skeletal health of these young individuals. Leptin is one of the most important adipose-derived hormones. It is a protein derived hormone that weighs about 16-KDa.It has an important role in the regulation of energy intake and energy expenditure which includes metabolism of appetite $[4,5]$. Vitamin $D$ has a profound role in negatively controlling the leptin secretion in human adipose tissue. After the discovery of Leptin in 1994 a large amount of research has been done to elucidate the physiological significance of leptin $[5,6]$. The mechanism of action of leptin is by binding to receptors in the brain and exerts its metabolic activities as a hormone [7]. There is the stimulation of lipolysis and inhibition of lipogenesis by leptin. Extreme overeating which leads to massive obesity occurs as a result of the genetic defect in leptin and its receptors. Leptin has a positive correlation with body fat content in healthy humans and negatively correlates with a reduction in energy and fat content $[8,9]$. Body fat which is present in our body is an essential part of it. Leptin, resist in and adiponectin are some of the hormones which is produced by the body fat. The main functions of body fat include providing an energy source to the body. Apart from it also acts as heat insulator and shock absorber and also as a source of estradiol in women. There are two types of body fat. They are essential fat and storage fat. Essential fat has an important role in normal and healthy functioning of the body. Percentage of essential fat is about $3 \%$ in men and about $12 \%$ in women. Storage fat is deposited in the skin around the muscles and the internal organs.it protects the internal organs from injury. Similar amounts of storage fat are found both in men and women.
When there is an increase in body weight there is an increase in storage fat. Since storage fat is expandable it leads to obesity. Body Mass Index (BMI) has a significant correlation with total body fat content. It describes the relative weight for height and it is not gender-specific $[10,11]$. The study aims to study the levels of vitamin $D$ and leptin levels based on BMI among medical students.

\section{Materials and Methods}

Study setting: The present study was carried out in the Department of Biochemistry in Meenakshi Medical College and Research Institute, Kancheepuram, Tamil Nadu.

Ethical consideration and permission: The study was carried out after obtaining the institutional ethical committee approval. Written informed consent was obtained from all the participants in the study.

Study design: The present study was a comparative study

Study duration: The present was conducted from 01- May- 2013 to 31-July-2013

Sample size: 100 randomly selected medical students who were age and gender-matched were included in the study who belong to different socioeconomic and religious backgrounds.

\section{Inclusion criteria}

01 . Age group between 19-22 years of age

02. Male and Female students

\section{Exclusion criteria}

01 . Age less than 19 and more than 22 years of age.

02. Hormonal disorders.

03. Renal and liver disorders

04. Vitamin D supplemented individuals.

Data collection: Vitamin D, Leptin and Body Mass Index were the parameters which were measured in the study. $3 \mathrm{ml}$ of blood was collected for the estimation of biochemical parameters. The blood drawn was allowed to coagulate and the serum was separated by centrifuging and stored at $-20^{\circ} \mathrm{C}$ until assayed. Vitamin $D$ was measured by direct Enzyme-Linked Immunosorbent Assay (ELISA) kit method.

Leptin was measured by direct Enzyme-Linked Immunosorbent Assay (ELISA) kit method based on the sandwich principle. After removal of their footwear subjects' weight were measured with a 
Beam balance scale, height was measured in a stadiometer to the nearest $0.5 \mathrm{~cm}$. Their BMI was calculated using the formula

$\mathbf{B M I}=$ Weight in $\mathrm{kg} /$ Height in $\mathrm{m} 2$

Data analysis: Data were analysed using the Statistical Package for Social Science (SPSS). Range, mean, SD, and median were expressed as quantitative data. Data and frequency were expressed qualitatively. P-value was assumed to be statistically significant at 0.05 .

\section{Results}

Table-1: Relation between vitamin $d$ and leptin based on body mass index.

\begin{tabular}{|l|l|l|l|l|}
\hline Particulars & $\begin{array}{r}\text { Normal } \\
\text { BMI }\end{array}$ & $\begin{array}{r}\text { Increased } \\
\text { BMI }\end{array}$ & \multicolumn{2}{|c|}{ P-valve } \\
\hline $\begin{array}{l}\text { Number of } \\
\text { participants }\end{array}$ & 36 & 64 & \multicolumn{2}{|c|}{ NA } \\
\hline $25(\mathrm{OH}) \mathrm{D}$ & $34.8 \pm 2$. & $17.2 \pm 1.6$ & $\begin{array}{l}\text { P<0.0001 (Normal } \\
\text { BMI and Vitamin } \\
\text { D) }\end{array}$ & $\begin{array}{l}\text { (Increased BMI and } \\
\text { Vitamin D) }\end{array}$ \\
\hline Leptin & $4.0 \pm 0.6$ & $12.8 \pm 1.8$ & $\begin{array}{l}\text { P<0.0001 (Normal } \\
\text { BMI and Leptin) }\end{array}$ & $\begin{array}{l}\text { P<0.0001 } \\
\text { Increased BMI and } \\
\text { Leptin) }\end{array}$ \\
\hline
\end{tabular}

$\mathrm{P}<0.001$ is considered significant

NA- Not applicable; The observed results in Table 1 indicate that when there is an increase in BMI there is a decrease in Vitamin D levels which is evident from the mean values of vitamin $D$ in normal BMI and Increased BMI which is $34.8 \pm 2.0$ and $17.2 \pm 1.6$ respectively.

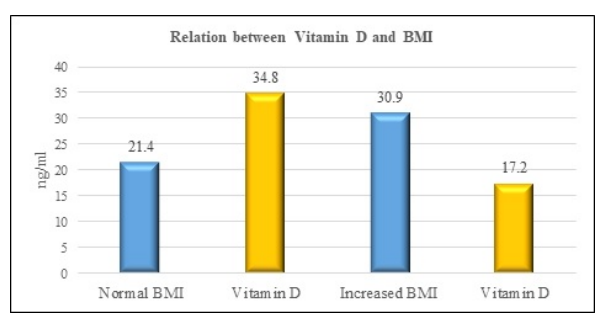

Fig-1: Relation between BMI and vitamin D.

The mean value of leptin in normal and increased BMI are $4.0 \pm 0.68$ and $12.8 \pm 1.8$ respectively which shows that there is an increase in leptin levels.

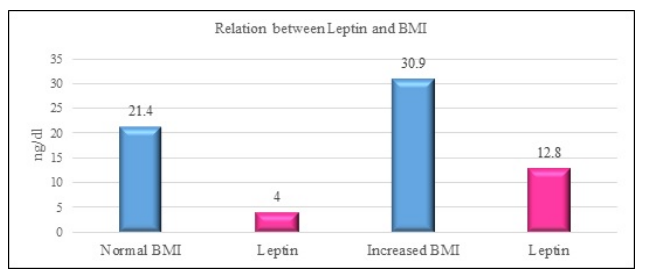

\section{Fig-2: Relation between BMI and leptin}

From the above results it is shown clearly that there is hypovitaminosis and leptin resistance when there is an increase in BMI.

\section{Discussion}

Vitamin $D$ which is a fat-soluble vitamin is derived from secosteroids. vitamin D2 and vitamin D3 are important related compounds of vitamin D. Apart from playing an important role in the metabolism of calcium vitamin $D$ plays an important role in the maintenance of skeleton, immunity and control of proliferation and differentiation of cell [12]. Due to non -calcaemic effects of vitamin $D$ there is an increase in interest in studying the role of vitamin $D$ in the human body [13]. The primary source of vitamin $D$ is the irradiation of solar UV-B (wavelengths of 290-315 $\mathrm{nm}$ ). There are limited dietary sources of vitamin They include oily fish, cod liver oil and egg yolks. Vitamin D2 and Vitamin D3 are the two forms of vitamin D. Irradiation of yeast and plant sterol such as ergosterol are sources of vitamin D2. Sources of vitamin D3 include oily fish, Codliveroil and synthesis from skin [14]. There is an intermittent synthesis of vitamin D from the skin and dietary sources. Vitamin D inadequacy occurs due to irregular intake of Vitamin $d$ irrespective of the source. Pre-vitamin D3 formed in the skin is converted to vitamin D3 by the skin. In the liver hydroxylation occurs which converts both vitamin D3 and vitamin $D$ into $25(\mathrm{OH}) \mathrm{D}$ and then in the kidney into its active form 1,25dihydroxy vitamin D. The major circulating metabolite of vitamin $D$ is serum $25(\mathrm{OH})$ D and it reflects the cutaneous synthesis and dietary intake of vitamin $D$. The standard clinical measure of vitamin $D$ status is serum $25(\mathrm{OH})$ D. $1,25(\mathrm{OH}) \mathrm{D} 2$ which is the active form of vitamin $D$ should not be measured to determine the status of vitamin D [15]. Previous studies conducted have shown that inadequacy of vitamin $D$ has been reported in across different ages, seasons and different geographic locations. Inadequacy of vitamin $D$ has been reported in young adults and in healthy school children. Low vitamin D levels less than $20 \mathrm{ng} / \mathrm{ml}$ has been reported in $36 \%$ of healthy young adults aged 18 to 29 years [16]. Studies which were conducted recently have shown that body mass index and body fat content have an inverse relationship with vitamin $D$ [17]. Leptin is a hormone which is synthesised and released from white adipose tissue. It is a 167amino acid hormone which weighs about $16-\mathrm{kD}$ 
Which is derived from of gene product. The main sources of secretion of leptin in the human body are gastric mucosa and placenta. The gastric mucosa is only tissue which secretes leptin in an exocrine manner rather secreting it in an endocrine fashion. Plasma leptin exhibits a diurnal variation in humans with a pulsatile and circadian pattern. There is a peak in the secretion of leptin at night and reaches its nadir in the morning. When leptin is administered to mice which are deficient in ob/ob gene that codes for leptin and to mice which are of wild-type obese, there is a decreased food intake [18]. Furthermore, Leptin also causes an increase in caloric expenditure and weight loss. There is also an established positive correlation of leptin with adipose tissue mass. From the observations above it has been postulated that leptin acts as a signal to the brain from the adipose tissue thereby regulating the body fat mass. In addition to playing an important role in hunger metabolism leptin also has mitogenic and antiapoptotic properties [19]. Body Mass Index (BMI) is based on the mass (weight) and height of a person. It is defined as the weight of the body which is expressed in kilograms divided by square of the height in $\mathrm{m} 2$. Based on the tissue mass (muscle, fat and bone) and height as a rule of thumb Body Mass Index (BMI) is conveniently used to categorize a person as underweight, normal weight, overweight or obese [20]. Body fat may be accountable for the weight excess or deficiency in part. Other facts like muscularity also has a significant role in altering Body Mass Index. Based on WHO classification Body Mass Index (BMI) of less than 18.5 is categorized as underweight.BMI equal or greater than 25 is categorized as overweight. Body Mass Index above 30 is categorized as obese [21]. Previous studies conducted have shown that leptin decreases bone formation in mice and sheep $[22,23]$. Matsunuma et al. [24] has reported that there is an increase in circulating levels of PTH in mice after the administration of leptin. Glauber HS et al. [25] has reported that there is an inverse relationship between BMI and osteoporosis. Based on the study conducted by Menendez et al. [26] it has been shown that there is a negative and powerful control by vitamin $\mathrm{D}$ on human adipose tissue which secretes leptin. Obese individuals even after prolonged exposure to UV radiation are at a disadvantage of producing active vitamin. Obesity which induces leptin production leads to decreased conversion of vitamin $D$ in to its active form 1,25 $\left(\mathrm{OH}_{2}\right)$ Vit D. In the present study, out of 100 students who were enrolled 36 of them were with normal Body Mass Index. In the current study,
64 individuals had an increased BMI. The prevalence of Increased BMI which is observed in the current study was similar to that of the general population in India. In the current study, 64\% of undergraduate medical students were with increased Body Mass Index which was almost similar to study conducted in West Bengal in India among undergraduate medical students [27]. Individuals with normal BMI had normal vitamin D levels (pvalue $\leq 0.0001$ ). Those individuals with increased Body Mass Index there is a decrease in vitamin D levels(pvalue $\leq 0.0001$ ). Several potential mechanisms have been put forth related to obesity causing decreased serum 25-hydroxyvitamin D levels. Kondarsen et al. have suggested that due to sequestration of vitamin $D$ by adipose tissue there seem to be low circulating vitamin $D$ concentration in obese individuals [28]. Moreover, based on the study conducted by Blum et al. in which vitamin $D$ is measured in 17 obese individuals and they have reported an inverse relationship between amount of fat tissue and serum vitamin D concentration which provides further evidence of storage of vitamin $D$ in fat tissue of obese individuals [28]. Li Jet al. have put forth a suggestion that due to increasing adiposity there may be increased catabolism of vitamin D due to local action of 24-hydroxylase enzyme which is found in human adipose tissue. Moreover, they have also suggested that there is a lower rate of synthesis of vitamin D in liver in obese individuals when compared to lean individuals [29]. Furthermore, leptin levels were normal with individuals of normal BMI(pvalue $\leq 0.0001)$ which was similar with the study conducted by Menendez et al. There is an increase in leptin levels among the individuals with increased BMI(pvalue $\leq 0.0001)$. The results obtained in the present study were similar with the results of the previous studies. Based on the physiological actions of leptin in humans it has been shown that there is a strong positive correlation between serum leptin concentrations and the percentage of body fat [30]. Based on the animal studies conducted by Pelley et al. in which there is a decrease in food intake, adiposity and body weight in leptin-deficient ob/ob mice after the administration of leptin. Based on the observations made Corrriea et al.in agouti yellow obese mice the concept of selective leptin resistance in which the resistance is limited to metabolic activities of leptin such as satiety and weight-reducing and it spares the renal sympathetic activation effects [31]. This concept collaborated well with findings of the study recently carried out in diet-induced obesity model by Rahmouni et al [321. Based on the recent studies 
In humans (Lonnqvist $F$ et al, Hamilton BS et al.,) and rodents (De Vos $\mathrm{P}$ et al., Funahashi $\mathrm{T}$ et al., Murakami T et al.,) serum leptin concentrations are regulated by the direct changes in the expression of ob gene thereby changes in body fat has an effect on changes in serum leptin [32] [33].

\section{Conclusion}

In the current study hypovitaminosis and increased leptin levels are observed with increasing BMI. There is a significant correlation with hypovitaminosis and increased leptin levels in relation to $\mathrm{BMI}$. The results obtained from the present study has shown that leptin and vitamin D can act as mediators of some effects related to obesity.

\section{What does this study add to the existing knowledge}

Increased BMI which leads to obesity is more prevalent among young students. The present study which involved medical students has shown that due to an increase in BMI there is hypovitaminosis of vitamin $\mathrm{d}$ and leptin resistance. The emphasis of the current study was on the need for increased physical activity and increased exposure to sunlight among medical students to prevent hypovitaminosis of vitamin $\mathrm{d}$ and obesity.

\section{Author's contribution}

Dr. J. Sivakumar: Concept, Data collection and Discussion Dr. Ursula Sampson: Discussion Mr. J.

Kumar: Data collection

\section{Reference}

01. Holick MF. Vitamin D- the underappreciated Dlightful hormone that is important for skeletal and cellular health. Curr Opin Endocrinol Diabetes. 2002;9(1)87-98. doi: [Article] [Crossref]

02. Tangpricha $V$, Koutkia $P$, et al. Fortification of orange juice with vitamin D- a novel approach to enhance vitamin D nutritional health. Am J Clin Nutr. 2003;77(6)1478-1483. doi: [Article] [Crossref]

03. Webb AR, deCosta BR, Holick MF. Sunlight regulates the cutaneous production of vitamin D3 by causing its photodegradation. J Clin Endocrinol Metab. 1989;68(5)882-887. doi: [Article] [Crossref]
04. Clemens TL, Adams JS, Henderson SL, Holick MF. Increased skin pigment reduces the capacity of skin to synthesise vitamin D3. Lancet. $1982 ; 1(8263) 74-76$. doi: [Article] [Crossref]

05. Matsuoka LY, Ide L, Wortsman J, MacLaughlin JA, Holick MF. Sunscreens supress cutaneous vitamin D3 synthesis. J Clin Endocrinol Metab. 1987;64(6)1165-1168.

doi: [Article] [Crossref]

06. Bikle DD. Vitamin D- role in skin and hair, InFeldman D, ed Vitamin D Vol 1, 2nd ed. Elsevier Academic Press; San Diego, California. 2005;609-630.

[Crossref]

07. Hosomi J, Hosoi J, Abe E, Suda T, Kuroki T. Regulation of terminal differentiation of cultured mouse epidermal cells by 1 alpha, 25-dihydroxy vitamin D3. Endocrinol. 1983;113(6)1950-1957. doi: [Article] [Crossref]

08. Smith EL, Walworth NC, Holick MF. Effect of $1 \mathrm{a}$, 25-dihydroxy vitamin D3 on the morphologic and biochemical differentiation of cultured human epidermal keratinocytes grown in serumfree conditions. J Invest Dermatol. 1986;86(6)709-714.

doi: [Article] [Crossref]

09. Heaney RP, Dowell MS, Hale CA, Bendich A. Calcium absorption varies within the reference range for serum 25-hydroxy vitamin D. J Am Coll Nutr. 2003;22(2)142-146. doi: [Article] [Crossref]

10. Binkley N, Krueger D, Cowgill CS, Plum L, Lake $E$, Hansen $K E$, et al. Assay variation confounds the diagnosis of hypovitaminosis D- a call for standardization. J Clin Endocrinol Metab. 2004; 89(7)3152-3157. doi: [Article] [Crossref]

11. Lips $P$, Chapuy MC, Dawson-Hughes B, Pols HA, Holick MF. An international comparision of serum 25-hydroxy vitamin D measurements. Osteoporos Int. 1999;9(5)394-397. doi: [Article] [Crossref]

12. Maetani M, Maskarinec G, Franke AA, Cooney RV. Association of leptin, 25-hydroxyvitamin D, and parathyroid hormone in women. Nutri Can. 2009;61(2)225-231. doi: [Article] [Crossref]

13. WHO. Mean Body Index (BMI). WHO. Available at [Article] [Crossref] 
14. Spina CS, Tangpricha $V$, et al. Vitamin D and cancer. Anticancer Res. 2006; 26(4A) 2515-24. [Crossref]

15. Wu K, Feskanich D, Fuchs CS, Willett WC, Hollis BW, et al. A nested case control study of plasma 25-hydroxyvitamin $D$ concentrations and risk of colorectal cancer. J Natl Cancer Inst. 2007;99 (14)1120-29.

doi: [Article] [Crossref]

16. Zittermann A. Vitamin D and disease prevention with special reference to cardiovascular disease. Prog Biophys Mol Biol. 2006;92(1)39-48. doi: [Article] [Crossref]

17. Autier P, Gandini S. Vitamin D supplementation and total mortality- a meta-analysis of randomized controlled trials. Arch Intern Med. 2007;167(16)1730-1737.

[Crossref]

18. Dong F, Ren J. Fitness or fatness-the debate continues for the role of leptin in obesityassociated heart dysfunction. Curr Diabetes Rev. 2007;3(3)159-164.

doi: [Article] [Crossref]

19. Calle EE, Thun MJ, Petrelli JM, Rodriguez C, Heath CW. Body-mass index and mortality in a prospective cohort of US adults. New Engl J Med. 1999;341(15)1097-1105.

doi: [Article] [Crossref]

20. Moghaddam AA, Woodward M, Huxley R. Obesity and risk of colorectal cancer- a meta-analysis of 31 studies with 70,000 events. Can- cer Epidem Biomarkers Prev. 2007;16(12)2533-47. doi: [Article] [Crossref]

21. Schwartz GG, Skinner HG. Vitamin D status and cancer- new insights. Curr Opin Clin Nutr Metabolic Care. 2007;10(1)6-11. doi: [Article] [Crossref]

22. Renehan AG, Tyson $M$, Egger $M$, Heller RF, Zwahlen $M$. Body-mass index and incidence of cancer- a systematic review and meta-analysis of prospective observational studies. Lancet. 2008;371(9612)569-578.

doi: [Article] [Crossref]

23. Matsunuma A, Kawane T, Maeda T, Hamada S, Horiuchi N. Leptin corrects increased gene expression of renal 25-hydroxyvitamin D3-1hydroxylase and-24-hydroxylase in leptindeficient, ob/ob mice. Endocrinol. 2004;145(3)1367-1375.

doi: [Article] [Crossref]
24. Buschemeyer WC III, Freedland SJ. Obesity and prostate cancer- epidemiology and clinical implications. Eur Urol. 2007;52(2)331-343. doi: [Article] [Crossref]

25. Glauber HS, Vollmer WM, Nevitt MC, Ensrud KE, Orwoll ES. Body weight versus body fat distribution, adiposity, and frame size as predictors of bone density. J Clin Endocrinol Metab. 1995;80(4)1118-1123. doi: [Article] [Crossref]

26. Menendez $C$, Lage $M$, Peino $R$, Baldelli $R$, Concheiro $P$, et al. Retinoic acid and vitamin $D$ (3) powerfully inhibit in vitro leptin secretion by human adipose tissue. J Endocrinol. $2001 ; 170(2) 425-431$. doi: [Article] [Crossref]

27. Park K. Text book of preventive and social Medicine. 19th ed. page 335.

[Crossref]

28. Konradsen S, Ag H, Lindberg F, Hexeberg S, Jorde R. Serum 1, 25-dihydroxy vitamin D is inversely associated with body mass index. Eur J Nutr. 2008;47(2)87-91.

doi: [Article] [Crossref]

29. Li J, Byrne ME, Chang E, Jiang Y, Donkin SS, Buhman KK et al. 1alpha, 25-Dihydroxyvitamin D hydroxylase in adipocytes. J Steroid Biochem Mol Biol. 2008;112(1-3)122-126.

doi: [Article] [Crossref]

30. Trayhurn P, Wood IS. Adipokines- inflammation and the pleiotropic role of white adipose tissue. Brit J Nutr. 2004; 92(3)347-355. doi: [Article] [Crossref]

31. Pelleymounter MA, Cullen MJ, Baker MB, Hecht $R$, Winters $D$, Boone $T$, et al. Effects of the obese gene product on body weight regulation in ob/ob mice. Sci. 1995,269(5223)540-543. doi: [Article] [Crossref]

32. Lönnqvist $F$, Arner $P$, Nordfors $L$, Schalling $M$. Overexpression of the obese (ob) gene in adipose tissue of human obese subjects. Nat Med. 1995;1(9)950-953.

doi: [Article] [Crossref]

33. De Vos P, Saladin R, Auwerx J, Staels B. Induction of ob gene expression by corticosteroids is accompanied by body weight loss and reduced food intake. J Biol Chem. 1995;270(27)15958-15961. doi: [Article] [Crossref] 